\title{
The Wide Road
}

\section{Carla Harryman and Lyn Hejinian}

\section{La grande route}

Comment et par où le désir circule-t-il? Peut-on le mesurer? Par ses thèmes et par sa forme, ce texte interroge les lieux et la mouvance du désir. La structure même du texte, avec ses deux colonnes, subvertit la singularité du désir: plurielle, la double voix déplace la sujette désirante d"elle' vers 'nous.' Tantôt un essai théorique, tantôt un journal, "La grande route" est à la fois une histoire d'amour et un poème ludique. Les chemins de la jouissance passent, et vont, ailleurs.

\section{An Essay}

Let's imagine that desires are perceptions more than motives, mediating the interplay of sensation with knowledge. In this, desires are a medium of acknowledgment, a way of identifying ourselves in terms of others. Although it's true that desires always want more, it's inaccurate to say that desires seek satisfaction - satisfaction would be a form of loss. Rather, what George Eliot says "of Voters and Sunlight," we would happily say of our desirous selves, that we "embrace all but possess only air."

We can't help but live in time, and yet we aren't looking for ultimate or even penultimate pleasures, choosing instead to go on

\section{Another Essay}

Too often curtailed! Too often abandoned! Too often speechless! Why measure desire? But have we now even approached it or seen it or known it?

This is the reason to measure desire even without realistic implements: to secure its prevalence.

Our task is paradoxical and thus ornamentally sexual. On the one hand, there is no measuring implement: neither a tadpole, or a flagpole or a ruler; although, the tadpole is an image of impregnation: a flagpole something to sit on top of, victoriously and even salaciously, and a ruler always good for a swat. On the other hand, even the mention of desire causes desire to commence 
with our desires, following them precisely the way persons follow their two eyes. What we see at any given moment, the out-stretched so-called field of vision, is bounded only by invisibility - by the skin and bones of our head that we admit but can't see - and by local constraints on visibility. But whatever is in the way of the view is itself something to see and our head holds our knowing, which is part of our desiring, that we see it.

To be mobile and desirous is to be unbounded among distinct things.

So with plaintive phosphorescent ebullience and waves of restraint we've been going almost anywhere, sometimes with a sense of necessity, sometimes with casual spontaneity, and always appreciatively, not because anything is the same as anything else but because everything is different. Our many love objects are incomparable, but they've made sense.

Vivo con el estomago aqui

y el corazon al otro lado del rio

(I live with my stomach here and my heart on the other side of the river)

says Lucha Corpi.

For instance, "when a man's glance is following certain house- measuring itself and its implements of measurement are as various as the imagination.

But be careful: sometimes the usages of measure, are more elegant than others. Those that start out with a series of discrete and formal gestures are sometimes those that provide the context for the greatest improvised abandon. A word carefully placed can erect a nipple.

We are greasing our palms with palm grease before we count our lovers, those who grease our recollections: rooms fill up with each other. The eucalyptus, the must, the piss, the sweet grass, and pastiche of the rooms fill the recollections as we grease our palms to count our lovers. Let us not, however, deceive anyone into thinking that counting lovers is a measure of desire. Measuring desire is never a quantifying of lovers; although, sometimes we imagine them all in the same room together as a substitute for a furnace in winter.

Desire measures itself in the distance, between itself and its object, which advances and is always advancing within time, all the way through all the climaxes it continues its strategies: even when curtailed, abandoned and without words. 
hold preparations, especially those for a meal, there is apt to be a look on his face that combines religious attention, boredom, and fear," according to Colette. We have seen that man without stomachs here and our hearts across the river. And all the fabulous factions of desire, which can be, also, aggravating. Sometimes happiness is at war with these factions, according to Kathy Acker and other esteemed compatriots who face our time with other time and elsewhere in our stomachs, where we live.

The man now staring at the woman cooking as if she were a priest at Mass is not staring at us. We are watching him watching her, as if all of us were gerunds to infinity or a Robert Smithson sculpture but out of reach, across the river. Between the man and the woman rolls the inchoate river of desire. And this river, according to our thesis is voracious, always redolent of more.

Although female, truly, we are neither man nor woman in this scene. The desirous observer, as if a river, flows by unnoticed. And yet, this sensation and notion of non-cultured sexuality is an illusion that grants us a fickle freedom, which is not superior to anything.

Let us explain. Our friend, C., was in the museum where in a
Desire is regulated by foresight, which is to say by itself, desire, looking ahead towards its object, which it discovers through an act of will but without knowing what to request.

But what of regret, that form of hindsight which is an erotic punishment, an exacerbator, the one that makes us plot. Missed occasions, shortened visits, interruptions - life measures desire.

One early morning in a small city diminished by hazy autumn sunlight we straddled a rental pony and relentlessly rode against the flow of pedestrians. A man jabbed a book at the head of the pony and we grabbed the book. It spoke of our copulating with Great Danes. A policeman whistled at us and we waggled our fingertips but didn't stop. He shouted to passersby that we had fucked with ants.

Such things are a nuisance but there's nothing here to regret. True or false are only applicable to what happens.

It's what hasn't happened that we could regret - and measure but only because they didn't happen.

We can't measure what has happened, because whatever has happened has endless repercussions, currents of effect and possibility like Phlegethon, in flames and engendering whatever is to 
little sequestered gallery was a precious, although not petite, but rather crownish glass sculpture of a woman pristinely being eaten by a man as if two figures on top of a wedding cake had undressed and turned into Bambi. C. was contemplating the lavender blue of the glass babies, when she realized that a male mausoleum guard was looking over her shoulder. The man, having failed to maintain his look of religious boredom, turned into an intrusive horse fly. C. exited her meditation, taking her desirous mobility elsewhere.

Now we think that if it had been we instead of she in that frosty and diminutive corner observing the fetish, we might have made a date with the guard to meet us after work. An alternative would have been to hoot him off stage. The object would surely have been coincidental when compared to us.

In any case, the object would soon be a fleck of memory, engulfed by many views.

It's thanks to the sustained memorizing sensations provoked by such flecks (afloat just here, in the light of retrospect) that we can replace any object, lodging ourselves in its experiences, which are now our own. We stand in the warm blue air of its rough come, the objects and events of our desire.

Yesterday a man ran his fingers through our hair. But his train arrived. He could have taken a later train, but we failed to say so. We regret that. But only incrementally, through stages of the imagination, measured according to the time it takes between now and the moment when we remember the gesture but cease in our fanciful senses to respond.

And what of loneliness born of regret? Do we have the right to speak of it? We are an unusual creature, since we are set apart from loneliness compositionally for the duration of our life; even though we, like others, suffer life's unexpected losses and our own inexact finitude. Now here is the story of a lonely woman, and we ask you to think along with us and consider what would have differed if we the plural had experienced her singular story: A doorway was half made. Did it protect an interior space or define an enclosed space? It would be possible to spend hours on the assumptions, nay faults, of our preceding question as one could also spend on the faults and assumptions of our protagonist, who although singular shares our profession, and who walked 
dream. A ghost's breath on our breasts frosts them. Or, as Zora Neale Hurston says, we "have memories within that come out of the material that goes to make us."

But to see (or otherwise sensewe, among other things sleepers, don't mean unduly to privilege the eyes) a thing (an object, maybe - an almost mammalian potato, perhaps - or an incident or event - say, the escape of the gang of female robbers last Saturday from the coffee house) is a kind of deferral. Or, rather, when sensation is aroused the result is commitment, not fulfillment.

We float. Not so casually. The two sides of the river have never coincided. But in our sensations of the river, bubbles follow brainpaths and our memory of water undulates and prevails. Afloat and following we slide along both surfaces - and no impression, however distant from another, is wiped out.

An amazing memory - voluminous and tenacious - is part of our physiological strength and maturity. Forming diverse and multiple associations, we know how much there is to desire and how well it can be desired.

It's true that young men have an excellent memory for facts connected with their own pursuits. But the more we remember the clustering and the through the half-finished doorway and bumped right into a man with whom she fell unmistakably and irrevocably in love.

$\mathrm{He}$ was not particularly great to look at but rather a hodgepodge of many others whom she had admired in the past, with his short greying hair, a gawkingly awkward height and an uninspired mustache. When he spoke, she was certain he was a mathematician and when she touched his hand she experienced the entire universe as being sucked into her lamp-lit body, bouncing and mingling among her sexual organs with limitless teasing, tickles, and ostentatious pressures. Now, with every increment of motion within, her desire to expel the inhaled universe into an explosion of song sliding down the bows of a viola through the coal-ridden creases of earth rocketing back out in flame and riverlashing liquid became an object unto itself. He seemed as surprised as she by this event, which was so absolute that there was nothing to say, but he did want to know when he could see her next. She tried to remember what had been going on the minute before she'd met this man, and failed. While she attempted this recollection, a boulder crashed down the side of the Eastern hills behind them: the falling boulder was the precursor 
gulf - the verification, the view the more erudite and suggestive all desirable facts become.

And so, one might ask, if facts are all animate and desirable at once, is it true that what we write of is engendered by the tenacious impulse to possess, consume, absorb fluidly and indiscriminately and thus confirm or register what has been noted men most fear in women? In other words, their encompassing unboundedness? (This is not to say that we ourselves agree that this is in fact what men most fear in women: that has been a conclusion too easily arrived at: it is the claim or notation we point to here). Is the material that goes into making us what we would select if we would choose it? Does this great freedom of language, which we employ to create this journey, undo what we have sought playfully to undo?

Sometimes the best way to undo a trap is to take it apart quietly without calling attention to it. But not always.

This version of undoing, to which we refer, is pleasure when it slips around, as if in loosened shoes. There are other versions too: when one looks at desirable objects for a long time, for instance a series of Morandi paintings, the entire world reveals the structure of the to an enormous avalanche. As the Eastern hills gave way to a force, or weakness, no one had anticipated, the man, the woman, and others ran for their lives, climbing to the high ground of the northern mesas. Although the woman could see the avalanche, she could no longer discern the details and wondered like a detached observer in a dream what was the extent of the injury to people and their houses.

When all was safe enough, the woman wanted to see where the man lived. They walked to a house, climbed some stairs, and faced a room of beds, full of sleeping children covered in orange, red, and brown comforters. They were a snorting, noisy group of sleepers, motherless and obscure. The woman suddenly recollected the paper she had been writing on the 18th century before all this had happened. The ghosts of Sade \& Rousseau danced in a storm around the youngsters.

The man, perhaps out of embarrassment, said nothing, but there was nothing that could restrain her from seducing him.

The man was like Rousseau in that he measured his inspiration according to the scales of nature and exposed himself to nature's danger, but he was unlike Rousseau in that he had children about whereas Rousseau had 
aesthetic objects as if the world itself has become transparent to them. One expands, or expounds, within the other and distinctions are obscured. And we have put a certain pressure on pleasure to press it into realms not typically identified with it as a way of obscuring and testing the boundaries of what we normatively think of as distinct.

Thus we are comedians who turn traps into songs. Welove what we must love/And do what we must do/Within some sad order/Of existence/brought from me to you. And detach as we sing. Having undone the use of self as singular. Having compromised singularity erotically. No longer a woman faced with men but a creature ourself composed of facets: of force or brevity, distance or proximity, detection or dissent, lungs or gear. There is a world that hovers around the senate absorbing the material of memory into its potential femininity.

At this moment this can not be said in any other way, because the prior order, unlike the senate, that supports its seed in memory is not an articulated social form. And thus the material that comprises us, presents itself in the queendom of unacknowledged knowledge, a combination of visitor and something inhuman. deposited each of his children at infancy in an orphanage.

The man was like Sade in that the grunting functioning polymorphic sleeping scene exacted from him not discretion but his own abandonment - a wild and extreme acquiescence-so that he, a voluptuous non-entity, might slide, singular and incomprehensibly prolonged, into nothingness - which was the woman and her loss.

Loneliness is nothing encompassing abandonment.

Regret (which is a sensuous deferral of pleasure) precedes it.

Of course, artistically we have no regrets. We desire with definition. But the loneliness of the lonely woman is hers because something has been overly defined. When we mentioned the half-made door, did you picture an aperture or a 7 by 3 foot board made to swing on hinges?

Those hinges have the syntax of dashes. The lonely woman is lacking links.

In her loneliness the past seems vast, no longer curtailing her but for the same reasons (whatever they are) containing nothing. The man who is somewhat Sade and somewhat Rousseau and not great to look at stands out therefore, providing her with the only pressure she receives. 
The rigidity of the shadow of a telephone pole against the wall needs a prolific counterpart, a voluptuous critical instability. The utterance, "How much we want you and you!" will be articulated a thousand times and each of those times will engender another thousand, and they are all the shadows of telephone poles. And we are humming.

But likewise we might have been silent, remaining silent in unstoppable voluptuous mutability (this should in no way be mistaken for yielding), lolling in illumination, having known all along that what we want is to create this journey and exactly precisely and in detail - not to stop it.

And here there seems to be a difference between plan and pleasure. It's much the same as the difference between ideology and attention. Each intention has its motive - and every pleasure to exist must be in some sense an object of experience. Pleasure slips around differences and makesour comedy a plan. Systems of belief make us laugh with pleasure. We laugh so boisterously that we call attention to ourselves and make men afraid because we are "animate and desirableat once."

Eventually, of course, being animate and desirable will
Today we were idiotically baffled when the houseplants we had put in the sun on the small table near the window facing south turned out to be standing in shadow. Did we think that things stand still?

If we don't watch the sun move, nothing happens - nothing repeats - nothing exists.

And thus, measurement is among us and overhead. This being the effects of the sun who doesn't measure but serves as a device. The lonely woman of our profession has written her way out of her romance, this writing profession being her jurisprudence against which romance is considered. She floats away in a whisp of thought leaving us holding hands on the wide road, linked and because a product of the imagination(s), autonomous in that we are separated from any kind of human or animal necessity we so desire to be separated from at any given moment.

If loneliness is the experience of separation, then it can be, through its negativity, a measurement of desire. Our lady could keep a journal of separated and abandoned moments; sometimes she calls these the effect of her periods of intolerance, which are deviously cyclical. 
conclude our comedy, but not until we have marked our ready acceptance of human participation all over our life - which is to say, when we have embedded our comedy.

Comediennes are not frothy pedagogues. From ancient times, men have entered the realm of the sacred wearing masks, and women have done so naked.

"Our knowledge desires you!" That is how the comediennes might address the bird on the wire singing "chirp tic tic" and the hard shadow of the telephone pole wobbling beside it.

The air is warm, eddies of humidity are stirred up here and there by bees, disregarding the limits of human action. Beside the road is a man in a hat plowing the field of vision behind a gray horse. We wave to catch his attention - then yelp and leap back suddenly, trip, and fall flat on our back in the dust, stung on the breast by a bee. The man can't help but laugh at this touch of ugliness and the momentary incongruity. But he runs to us, jumping over the ruts, carrying a bit of wet mud.
10/6 Tolerable heat. But heat nonetheless. Rejected Tim in an irrigation ditch. Now I am climbing the walls of my inner strength.

10/8 Saw Philip from a distance. I am on top of the wall. Waiting for the fall.

10/9 Fell.

10/11 The sun at its peak competes with his comforting moans.

$11 / 6$ Philip is gone, sick of competing with the universe for my affections.

$11 / 7$ The universe is intolerant of my needs. Menstrual bleeding reminds me that I may not care about any of this tomorrow. But I never can believe it.

11/8 A bit more symptomatizing and I will forget everything. I still prefer the universe to Philip; even though my cavities are filled with extra holes.

$11 / 9$ Philip says he is willing to play second fiddle.

11/10 I tell him he has to play third: to the universe and then to my theoretical writings. He says I am only saying this to humble him. 